\title{
MOLECULAR ASSESSMENT OF ORAL STREPTOCOCCUS MUTANS ISOLATED FROM PATIENTS WITH DIFFERENT AGES AND CARIES ACTIVITY VIA SELECTIVE MEDIA AND PROTEIN PATTERN
}

\author{
Naglaa Ezzeldin *, Hisham Elshishtawy ** and Mona Mohamed ***
}

\begin{abstract}
Objective: Comparative evaluation of various media compositions for Streptococcus mutans (Strep. mutans) best propagation, pointing out the diversity in Strep. mutans clinically isolated from patients with different caries behavior and ages using molecular tools.

Methods: The case control study included ninety outpatients from Faculty of Dentistry, October University for Modern Sciences and Arts, Cairo, Egypt, that were divided into three age groups (35, 6-12 and 18-25 years). Each group was subdivided according to the caries behavior into caries free and active subgroups. Salivary samples were collected. Six culture media were used to plate the diluted saliva. They were Mitis Salivarius and tellorite (MST), Mitis Salivarius, bacitracin and kanamycin (MSBK), Mitis Salivarius, bacitracin and tellorite (MSBT), Trypticase media, glucose, sucrose, tellurite, and bacitracin (GSTB) and yeast, cysteine, sucrose and bacitracin (YCSB) agars. Polymerase Chain Reaction technique was used to detect Strep. mutans using primers. Total protein profiles were analyzed through polyacrylamide gel electrophoresis.
\end{abstract}

Results: GSTB media yielded the highest percentage of Strep. mutans colonies. Regarding the protein profile, proteins $(43,51,65,74$ and $87 \mathrm{kDa})$ were significantly less detected in 18-25 age group compared to the other groups. About the caries activity, there was a significant difference in 122 and $170 \mathrm{kDa}(P=0.01)$ between caries free and active participants.

Conclusions: Media structure may play significant role in Strep. mutans recovery. Protein bands were less commonly observed in young adults, but the inserting result showed that only two bands were found to differentiate between caries active and free participants.

KEY WORDS: Dental caries; culture media; PCR; Streptococcus mutans.

\footnotetext{
* Department of Pediatric Dentistry, Faculty of Dentistry, October University for Modern Sciences and Arts.

** Department of Microbial Genetics, Agricultural Genetic Engineering Research Institute, Agriculture Research Center.

*** Department of Conservative Dentistry, Faculty of Dentistry, October University for Modern Sciences and Arts.
} 


\section{INTRODUCTION}

Dental caries is the most common disease affecting oral cavity ${ }^{1}$. Streptococcus mutans (Strep. mutans) is the key etiological factor of dental caries in humans. The role of Strep. mutans in the initiation of dental caries depends not only on its acidogenic and aciduric ability ${ }^{2,3}$, but also on its ability to produce glucans that colonize Strep. mutans on the tooth surface. Furthermore, Strep. mutans produced proteins that may contribute to its virulence in dental caries ${ }^{4,5}$.

These proteins could also be attributed to the difference in virulence factors of Strep. mutans between individuals with different prevalence of caries, despite the presence of similar counts between different individuals ${ }^{4,6}$.

Several methods have been used for the detection of Strep. mutans species, such as selective culture, molecular methods including Polymerase Chain Reaction (PCR), DNA probe and sodium dodecyl sulfate-polyacrylamide gel electrophoresis $(\text { SDS-PAGE })^{7,8}$.

Mitis Salivarius medium (MSM) supplemented with bacitracin and sucrose was targeted as selective media to isolate and characterize Strep. mutans ${ }^{9}$. Nevertheless, MSM showed restricted selection rule and displayed lower number of Strep. mutans relative to other types of media ${ }^{10,11}$.

PCR is a specific and rapid method capable of detecting Strep. mutans using specifically designed primers for glucosyl transferace gene amplification ${ }^{6}$. Total protein banding is one of the best molecular techniques for recognizing and differentiating Strep. mutans isolates at the level of the cell protein (extracellular expressed), and that is why this technique is used to measure the molecular weight migration of various bands ${ }^{12}$.

Identifying the type of microorganisms, particularly Strep. mutans, by using modern molecular tools and other factors that cause dental caries is important for determination of appropriate treat- ment for individuals of different ages and caries behaviors.

To our knowledge, using recent molecular methods such as SDS-PAGE of whole protein to differentiate between Strep. mutans species isolates from patients with various ages and caries activity was not sufficiently reported. Therefore, this study aimed to compare various media compositions for Strep. mutans best propagation, pointing out the diversity in Strep. mutans clinically isolated from patients with different caries behavior and ages using molecular tools.

The null hypothesis is that there are no differences between tested culture media in the detection of Strep. mutans. Also, there are no differences in the Strep. mutans protein pattern of the patients with various age and caries behavior.

\section{MATERIALS AND METHODS}

A case control study was approved from the Research Ethical Committee of Faculty of Dentistry, October University for Modern Sciences and Arts (MSA).

\section{A. Sample size}

The sample size calculation was based on comparing Strep. mutans between three age groups, and each age group was subdivided into caries free and active subgroups. As reported in previous publications ${ }^{6,13}$, the mean and SD of oral Strep. mutans in preschool children were $2.27 \pm 0.54$ in caries active subgroup and $1.61 \pm 0.54$ in caries free subgroup. In the young adults group, the mean and SD of oral Strep. mutans concentration were $3.31 \pm 0.85$ and $2.44 \pm 0.54$ in the caries active and free subgroups, respectively. Unfortunately, no data were found about the school children group. 2-way variance test analysis (MANOVA) was used assuming a small effect size of 0.1 , setting type one error $(\alpha)$ to 0.05 and achieving $80 \%$ power which resulted in 90 samples (15 in each subgroup) as the minimum proper sample size. Sample size 
calculation was performed using $\mathrm{G}^{*}$ Power software version 3.1.2 for MS Windows (Franz Faul, Kiel University, Germany).

\section{B. Recruitment of the participants}

Ninety participants who met the eligibility criteria were recruited from the outpatient clinics of the Faculty of Dentistry, MSA University, Cairo, Egypt, using consecutive participant sampling for the period from January to May 2019, after signing the informed consent either by the adult participants or the legal guardians of children. The participants were divided into three groups $(n=30)$ according to age. Group A included children with primary dentition (three to five years), group B included children with mixed dentition (six to twelve years) and group $\mathrm{C}$ included adults with permanent dentition (eighteen to twenty- five years). Each group was subdivided into two subgroups $(n=15)$; caries free (F) with undetectable caries, $\mathrm{D}_{\mathrm{ICDAS}} \mathrm{MFT} /$ $\mathrm{d}_{\text {ICDAS }} \mathrm{mft}$ (decayed, missed and filled index) $=0$ and caries active (A) with $\mathrm{D}_{\text {ICDAS }} \mathrm{MFT} / \mathrm{d}_{\mathrm{ICDAS}} \mathrm{mft} \geq 4^{14,15}$.

\section{Eligibility criteria}

All the participants were selected according to the following criteria; normal healthy patients without any diseases affecting salivary secretions, no history of anti-infection treatment for one month, in addition to xylitol and fluoride that had not been devoured during the last three months before the examination.

\section{Dental caries examination}

The International Caries Detection and Assessment System (ICDAS) was applied for clinical examination ${ }^{15}$. The tooth surfaces were examined with direct visualization, using a light reflector and an air syringe. Bitewing radiographs were not performed as a routine, but radiographs were taken when interproximal lesion was suspected. The cavitated lesions were properly restored after saliva sampling.

\section{Saliva sample collection}

Salivary samples were collected in the morning; participants were instructed to avoid eating at least one hour before sample collection. Unstimulated samples were collected by using sterile cotton swab that was held in the sublingual area for five minutes until saturation ${ }^{16}$. Then they were transferred to sterile labeled polypropylene tube. The tubes were transported in ice and handled within an hour.

\section{Preparation of media and bacterial culturing}

As for the tested culture media, MST (Control media) was prepared according to the manufacturer's instructions (Mitis Salivarius, HiMedia Laboratories, Mumbai, India). MSBK was taken from media arranged by Kimmel and Tinanoff 17 by adding five gm/L dextrose (Sigma Aldrich Company, St. Louis, USA). Based on the previous publications ${ }^{18-20}$, MSBT, Trypticase and GSTB were prepared. A new media formulation YCSB was prepared from the following components; Yeast extract 10 gm (Oxoid Company, Lenexa, USA), L-cystine 0.1 gm, Murachigee salts $20 \mathrm{gm}$, sucrose $100 \mathrm{gm}$ and bacitracin $0.2 \%$ (Sigma Aldrich Company, St. Louis, USA). The media were poured in agar plates and stored in $4^{\circ} \mathrm{C}$. Salivary swabs were immersed in one $\mathrm{ml}$ Phosphate Buffered Saline (PBS) and vortexed for one minute at $2500 \mathrm{rpm}$ by using vortex mixer (Stuart, Staffordshire, UK) to dislodge the bacteria, and then they were diluted to $10^{-3}$, aliquot $50 \mu 1$ of the diluted PBS were inoculated in each media plate. For each patient, ten plates were cultured. All plates were incubated in $10 \% \mathrm{CO}_{2}$ at $37^{\circ} \mathrm{C}$ for 48 hours. The developed colonies were screened later for Strep. mutans through PCR.

\section{E. Extraction of chromosomal DNA:}

Chromosomal DNA from the cultured bacteria was extracted as previously described ${ }^{21}$. After centrifugation (Eppendorf 5402, Hamburg, Germany), the precipitate was vortexed in the lyses solution, and the chromosomal DNA from the bacteria contained in the precipitate was extracted after being boiled for 10 minutes. 


\section{F. Polymerase Chain Reaction (PCR) experiments}

The primers were designed to amplify $433 \&$ $517 \mathrm{bp}(\mathrm{gtf} D \& \mathrm{gtf} B)^{22,23}$ as a detection tool for Strep. mutans in comparison to the standard strain (ATCC 25175) which represented the control group. The primers sequence are listed in Table (1). PCR amplification was performed in a GeneAmp ${ }^{\circledR}$ PCR System 9700, Perkin-Elmer (PE Applied Biosystems) programmed to fulfill 40 cycles after an initial denaturation cycle at $94^{\circ} \mathrm{C} / 5$ minutes. Each cycle consisted of a denaturation at $94^{\circ} \mathrm{C} /$ one minute, an annealing at $42^{\circ} \mathrm{C} /$ one minute, and an elongation at $72^{\circ} \mathrm{C} / 1.5$ minute. The primer extension segment was extended at $72^{\circ} \mathrm{C} / 7$ minutes in the final cycle. The PCR product was resolved in a $1.5 \%$ agarose gel with ethidium bromide $(0.5 \mathrm{ug} /$ $\mathrm{ml}$ ) in $1 \mathrm{X}$ TBE buffer visualized on UV light and photographed (Figure 1). The amplification reaction was carried out in $25 \mu \mathrm{l}$ reaction volume containing 1X PCR buffer, $1.5 \mathrm{mM} \mathrm{MgCl}, 0.2 \mathrm{mM}$ dNTPs, one $\mu \mathrm{M}$ primer, one $\mathrm{U}$ Taq DNA polymerase and $25 \mu \mathrm{g}$ templates DNA.

\section{G. SDS-PAGE analysis}

Total cellular proteins were extracted by resuspending cells extracted from GSTB media (the best media according to the present study results) in one volume of sample buffer and kept in $100^{\circ} \mathrm{C} / 5$ minutes and then for two minutes on ice. The supernatant containing total cellular protein was loaded onto $12 \%(w / v)$ SDS-PAGE gels and run at $45 \mathrm{~mA}$ for one hour, and then was fixed and stained with Coomassie brilliant blue (Bio-Rad Lab, California, USA) by the method of Laemmli ${ }^{24}$.

\section{Electrophoresis of protein gel}

TABLE (1) Primers used in PCR experiments

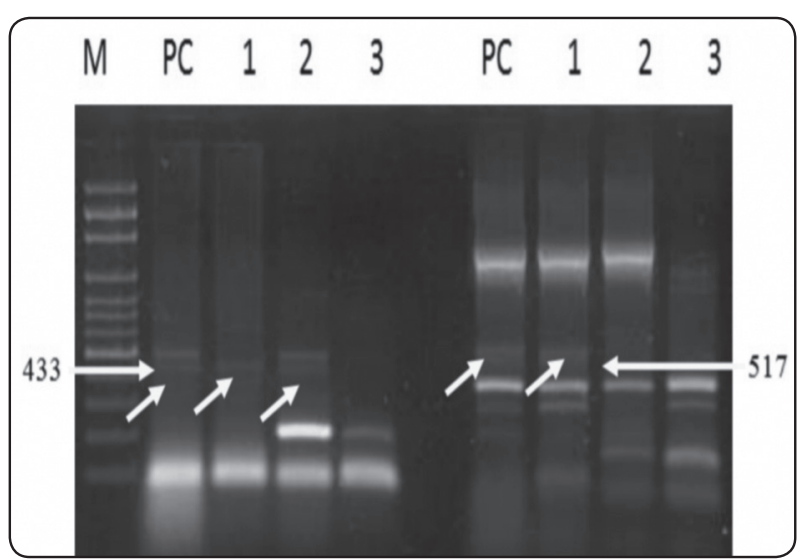

Fig. (1) A Polymerase Chain Reaction amplification of the $g t f$ sequences in chromosomal DNA from Streptococcus. mutans (Strep. mutans) strains using primers $g t f B-F$, $-R$ and $g t f D-F,-R$. M: molecular weight marker, PC: positive control Strep. mutans (ATCC 25175), lane 1-3: Strep. mutans isolated from patients.

The gel apparatus (Bio-Rad Laboratories, California, USA) was assembled and the lower and upper chambers were filled with the tank buffer. Loading of protein samples was done by Hamilton syringe $(10 \mu \mathrm{l})$. Pre-stained molecular weight protein marker from Bio-Rad was applied to the gel. Electrophoresis was carried out at about 100 volts $(\approx 20-30 \mathrm{~mA})$ in $1 \mathrm{X}$ Tris/glycine-SDS-running buffer for 1.5-2 hours.

\section{Staining and destaining of the protein gel}

The gel was stained in $50 \mathrm{ml}$ of staining solution $(0.125 \%$ coomassie blue R-250, 50\% methanol and $10 \%$ acetic acid) with shaking $(40 \mathrm{rpm})$ for six hours at $37^{\circ} \mathrm{C}$. Then it was washed once with distilled $\mathrm{H}_{2} \mathrm{O}_{2}$, destained by a destaining solution (40\% methanol and 7\% acetic acid) for at least two hours, photographed and analyzed. (Figure 2).

\begin{tabular}{|l|l|c|c|}
\hline Primer & Sequence $\left(\mathbf{5}^{\prime} \mathbf{-} \mathbf{3}^{\prime}\right)$ & Amplicon size (bp) & References \\
\hline $\begin{array}{l}\text { Gtf } D-F \\
\text { Gtf } D-R\end{array}$ & GGCACCACAACATTGGGAAGCTCAGT & 433 & 22 \\
\hline $\begin{array}{l}\text { Gtf } B-F \\
G t f B-R\end{array}$ & ACAATGGCCGCTAAGTCAACAGTTCATCGGTGGGCTTGG & 517 & 23 \\
\hline
\end{tabular}




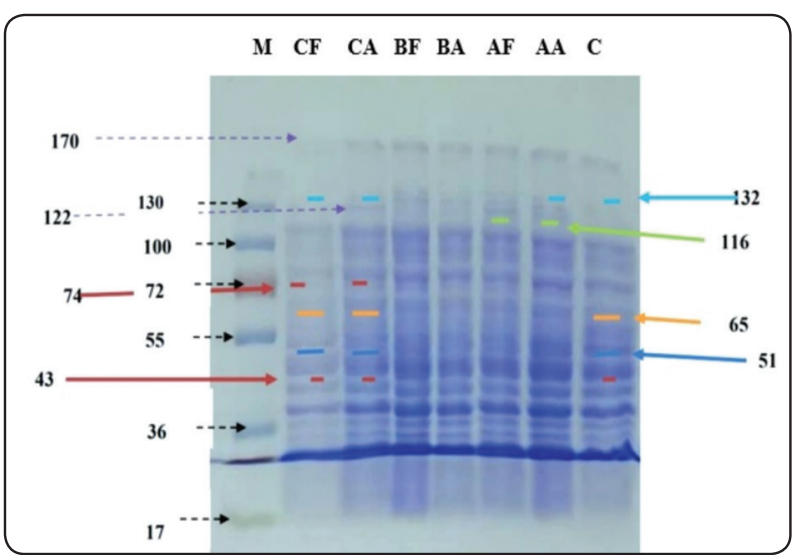

Fig. (2) sodium dodecyl sulfate-polyacrylamide gel electrophoresis analysis of protein extracts of control Streptococcus. mutans (Strep. mutans) and Strep. mutans isolated from patient groups, M: molecular weight marker, CF: caries free young adult, $\mathrm{CA}$ : caries active young adult, BF: caries free school children, BA: caries active school children, $\mathrm{AF}$ : caries free preschool children, AA: caries active preschool children and C: control Strep. mutans (ATCC 25175).

\section{Statistical analysis}

The data were statistically described in terms of mean $\pm \mathrm{SD}$, range, and $95 \% \mathrm{CI}$, or frequencies (number of cases) and percentages when appropriate. The data were screened for normality using Shapiro Wilk test and proved to be normally distributed $(P>$ 0.05). Comparison of numerical variables between the study groups was performed using one way analysis of variance (ANOVA) test. Within each group, comparison of the numerical variables was made using repeated measures analysis of variance (ANOVA) test. As for comparing categorical data, Chi-square (c2) test was performed. Exact test was used instead when the expected frequency is less than five. Two sided $P$ values, less than 0.05 , were considered statistically insignificant. All statistical calculations were done using computer program IBM SPSS (Statistical Package for the Social Science; IBM Corp, Armonk, NY, USA), Microsoft Windows, Version 22.

\section{RESULTS}

In this study, fifteen patients were involved in each subgroup according to the inclusion criteria. The mean of $\mathrm{D}_{\text {ICDAS }} \mathrm{MFT} / \mathrm{d}_{\text {ICDAS }} \mathrm{mft}$ caries index for all caries free and active groups were 0.01 and six \pm 0.1 , respectively.

\section{A) Detection of Strep. mutans colony forming unit (CFU) in different media:}

The percentage of growth of Strep. mutans on different types of media for different groups is presented in table (2). Concerning the total percentage of recovery for Strep. mutans in all groups, GSTB showed a significant growth of Strep. mutans compared to the other types of media.

On the other hand, a statistically significant difference was found between different groups regarding the type of media used to detect the growth of Strep. mutans. In Group A, the best media identified was GTBS. Whereas, MSBT media showed the highest recovery of Strep. mutans in CA group, however, in CF group, GTBS was found to be the best media. In BF and BA groups, trypticase and MSBK media were found to be the most suitable media respectively.

\section{B) Detection of total protein profile in control Strep. mutans and different clinically isolated Strep. mutans:}

The difference in the total cellular protein in different ages with various caries activity is presented in table (3). The protein expression in the control group was identified as $(\mathrm{n}=1)$. This corresponds to presence $(100 \%)$ or absence of protein $(0 \%)$, whereas the protein expression in the other groups $(n=15)$ was described as different percentages based on enhanced or reduced recognition of these proteins.

According to the participant's age, $116 \mathrm{kDa}$ was highly detected in group A compared to the other groups. Moreover, CF and CA groups showed 
TABLE (2) Mean, SD and CI of Strep. mutans CFU in tested media for each group of patients

\begin{tabular}{|c|c|c|c|c|c|c|}
\hline & & Mean & $\mathbf{S D}$ & $95 \%$ & Mean & P yolue $>$ ( \\
\hline & & Miean & SD & Lower Bound & Upper Bound & $F$ value \\
\hline & $\mathrm{AF}$ & 8.03 & 1.852 & 7.00 & 9.05 & \\
\hline & AA & 5.85 & 1.508 & 5.01 & 6.68 & \\
\hline & $\mathrm{BF}$ & 4.04 & 1.810 & 3.04 & 5.04 & \\
\hline Direp. mulatis C FO & BA & 2.37 & 0.735 & 1.96 & 2.78 & $0.01^{*}$ \\
\hline & $\mathrm{CF}$ & 4.53 & 0.948 & 4.00 & 5.05 & \\
\hline & $\mathrm{CA}$ & 3.70 & 0.709 & 3.31 & 4.09 & \\
\hline & Total & 4.75 & 2.228 & 4.28 & 5.22 & \\
\hline & $\mathrm{AF}$ & 8.51 & 1.745 & 7.55 & 9.48 & \\
\hline & AA & 5.35 & 0.839 & 4.88 & 5.81 & \\
\hline & $\mathrm{BF}$ & 4.29 & 0.905 & 3.79 & 4.79 & \\
\hline Strep. mulans CFU & BA & 4.17 & 0.631 & 3.82 & 4.52 & $0.01^{*}$ \\
\hline & $\mathrm{CF}$ & 4.74 & 1.265 & 4.04 & 5.44 & \\
\hline & $\mathrm{CA}$ & 5.19 & 1.071 & 4.60 & 5.79 & \\
\hline & Total & 5.38 & 1.841 & 4.99 & 5.76 & \\
\hline & $\mathrm{AF}$ & 7.13 & 1.437 & 6.34 & 7.93 & \\
\hline & AA & 2.56 & 1.087 & 1.96 & 3.17 & \\
\hline & $\mathrm{BF}$ & 3.26 & 1.157 & 2.62 & 3.90 & \\
\hline $\begin{array}{c}\text { Strep. mutans CFU\% } \\
\text {. }\end{array}$ & BA & 3.55 & 0.597 & 3.22 & 3.88 & $0.01 *$ \\
\hline & $\mathrm{CF}$ & 8.43 & 0.729 & 8.03 & 8.84 & \\
\hline & $\mathrm{CA}$ & 7.72 & 0.932 & 7.21 & 8.24 & \\
\hline & Total & 5.44 & 2.582 & 4.90 & 5.98 & \\
\hline & $\mathrm{AF}$ & 5.13 & 1.199 & 4.46 & 5.79 & \\
\hline & AA & 7.89 & 1.289 & 7.18 & 8.61 & \\
\hline Stron mutanc CEUO & $\mathrm{BF}$ & 7.69 & 0.876 & 7.20 & 8.18 & \\
\hline Sirep. mulans CNO & $\mathrm{BA}$ & 3.15 & 1.029 & 2.58 & 3.72 & $0.01^{*}$ \\
\hline & $\mathrm{CF}$ & 4.01 & 1.098 & 3.40 & 4.62 & \\
\hline & $\mathrm{CA}$ & 3.72 & 0.623 & 3.38 & 4.07 & \\
\hline & Total & 5.27 & 2.145 & 4.82 & 5.72 & \\
\hline & $\mathrm{AF}$ & 12.89 & 2.615 & 11.44 & 14.34 & \\
\hline & AA & 13.18 & 1.690 & 12.24 & 14.11 & \\
\hline & $\mathrm{BF}$ & 3.04 & 1.471 & 2.22 & 3.85 & \\
\hline Direp. mulats C FO & BA & 3.77 & 0.698 & 3.39 & 4.16 & $0.01^{*}$ \\
\hline & $\mathrm{CF}$ & 11.39 & 2.384 & 10.07 & 12.71 & \\
\hline & $\mathrm{CA}$ & 2.85 & 0.732 & 2.44 & 3.25 & \\
\hline & Total & 7.85 & 5.002 & 6.81 & 8.90 & \\
\hline & $\mathrm{AF}$ & 6.48 & 1.774 & 5.50 & 7.47 & \\
\hline & AA & 6.37 & 1.254 & 5.68 & 7.07 & \\
\hline & $\mathrm{BF}$ & 5.02 & 0.887 & 4.53 & 5.51 & \\
\hline Strep. mutans CFU & $\mathrm{BA}$ & 3.69 & 0.884 & 3.20 & 4.18 & $0.01 *$ \\
\hline & $\mathrm{CF}$ & 3.68 & 0.505 & 3.40 & 3.96 & \\
\hline & $\mathrm{CA}$ & 3.39 & 0.695 & 3.01 & 3.78 & \\
\hline & Total & 4.77 & 1.662 & 4.42 & 5.12 & \\
\hline
\end{tabular}


significantly low detected proteins with $\mathrm{kDa}(43$, there was no significant difference except $132 \mathrm{kDa}$ $51,65,74$ and 87 ). They ranged from $0 \%$ to $26.7 \%$ of participants. Similarly, these proteins were undetected in the control Strep. mutans except for which was insignificantly detected in AA, CF and CA groups. As for the summation of caries free (AF, 74 and 87 proteins that were positively identified. $\mathrm{BF}$ and $\mathrm{CF}$ ) and caries active patients (AA, BA and Regarding the caries activity of each age group, two proteins (122 and 170) as shown in table (4).

TABLE (3) Number and percentage of detected kDa proteins of control Strep. mutans and Strep. mutans isolated from patient groups

\begin{tabular}{|c|c|c|c|c|c|c|c|c|c|c|c|c|c|c|c|}
\hline \multicolumn{16}{|c|}{ Number and percentage of detection within the groups } \\
\hline \multirow{2}{*}{ kDa } & \multicolumn{2}{|c|}{ Control } & \multicolumn{2}{|c|}{ AF } & \multicolumn{2}{|c|}{$\mathbf{A A}$} & \multicolumn{2}{|c|}{ BF } & \multicolumn{2}{|c|}{ BA } & \multicolumn{2}{|c|}{ CF } & \multicolumn{2}{|c|}{ CA } & \multirow{2}{*}{$\begin{array}{c}P \\
\text { value }\end{array}$} \\
\hline & $\mathrm{N}=15$ & $\%$ & $\mathrm{~N}=15$ & $\%$ & $\mathrm{~N}=15$ & $\%$ & $\mathrm{~N}=15$ & $\%$ & $\mathrm{~N}=15$ & $\%$ & $\mathrm{~N}=15$ & $\%$ & $\mathrm{~N}=15$ & $\%$ & \\
\hline 27 & 1 & $100 \%$ & 12 & $80 \%$ & 13 & $86.7 \%$ & 11 & $73.3 \%$ & 11 & $73.3 \%$ & 15 & $100 \%$ & 15 & $100 \%$ & 0.16 \\
\hline 31 & 1 & $100 \%$ & 15 & $100 \%$ & 12 & $80 \%$ & 12 & $80 \%$ & 12 & $80 \%$ & 14 & $93.3 \%$ & 15 & $100 \%$ & 0.25 \\
\hline 36 & 1 & $100 \%$ & 15 & $100 \%$ & 15 & $100 \%$ & 14 & $93.3 \%$ & 14 & $93.3 \%$ & 14 & $93.3 \%$ & 15 & $100 \%$ & 0.79 \\
\hline 40 & 1 & $100 \%$ & 15 & $100 \%$ & 14 & $93 \%$ & 13 & $86.7 \%$ & 13 & $86.7 \%$ & 13 & $86.7 \%$ & 11 & $73.3 \%$ & 0.46 \\
\hline 43 & 0 & $0 \%$ & 15 & $100 \%$ & 15 & $100 \%$ & 11 & $73.3 \%$ & 11 & $73.3 \%$ & 3 & $20 \%$ & 4 & $26.7 \%$ & $0.01 *$ \\
\hline 47 & 1 & $100 \%$ & 12 & $80 \%$ & 15 & $100 \%$ & 15 & $100 \%$ & 15 & $100 \%$ & 15 & $100 \%$ & 15 & $100 \%$ & $0.02 *$ \\
\hline 51 & 0 & $0 \%$ & 15 & $100 \%$ & 14 & $93.3 \%$ & 13 & $86.7 \%$ & 12 & $80 \%$ & 0 & $0 \%$ & 2 & $13.3 \%$ & $0.01 *$ \\
\hline 57 & 1 & $100 \%$ & 1 & $6.7 \%$ & 3 & $20 \%$ & 2 & $13.3 \%$ & 2 & $13.3 \%$ & 1 & $6.7 \%$ & 2 & $13.3 \%$ & 0.22 \\
\hline 65 & 0 & $0 \%$ & 15 & $100 \%$ & 13 & $86.7 \%$ & 15 & $100 \%$ & 15 & $100 \%$ & 0 & $0 \%$ & 3 & $20 \%$ & $0.01 *$ \\
\hline 68 & 1 & $100 \%$ & 12 & $80 \%$ & 14 & $93.3 \%$ & 13 & $86.7 \%$ & 13 & $86.7 \%$ & 15 & $100 \%$ & 15 & $100 \%$ & 0.40 \\
\hline 74 & 1 & $100 \%$ & 13 & $86.7 \%$ & 14 & $93.3 \%$ & 12 & $80 \%$ & 12 & $80 \%$ & 3 & $20 \%$ & 4 & $26.7 \%$ & $0.01 *$ \\
\hline 79 & 1 & $100 \%$ & 14 & $93.3 \%$ & 15 & $100 \%$ & 15 & $100 \%$ & 14 & $93.3 \%$ & 15 & $100 \%$ & 13 & $86.7 \%$ & 0.50 \\
\hline 87 & 1 & $100 \%$ & 13 & $86.7 \%$ & 14 & $93.3 \%$ & 15 & $100 \%$ & 14 & $93.3 \%$ & 1 & $6.7 \%$ & 1 & $6.7 \%$ & $0.01 *$ \\
\hline 92 & 1 & $100 \%$ & 12 & $80 \%$ & 14 & $93.3 \%$ & 14 & $93.3 \%$ & 14 & $93.3 \%$ & 13 & $86.7 \%$ & 11 & $73.3 \%$ & 0.57 \\
\hline 99 & 1 & $100 \%$ & 12 & $80 \%$ & 14 & $93.3 \%$ & 15 & $100 \%$ & 15 & $100 \%$ & 13 & $86.7 \%$ & 12 & $80 \%$ & 0.30 \\
\hline 105 & 1 & $100 \%$ & 15 & $100 \%$ & 13 & $86.7 \%$ & 15 & $100 \%$ & 15 & $100 \%$ & 15 & $100 \%$ & 15 & $100 \%$ & 0.11 \\
\hline 116 & 0 & $0 \%$ & 14 & $93.3 \%$ & 13 & $86.7 \%$ & 3 & $20.0 \%$ & 3 & $20.0 \%$ & 3 & $20.0 \%$ & 0 & $0 \%$ & $0.01 *$ \\
\hline 122 & 0 & $0 \%$ & 2 & $13.3 \%$ & 2 & $13.3 \%$ & 1 & $6.7 \%$ & 1 & $6.7 \%$ & 2 & $13.3 \%$ & 13 & $86.7 \%$ & $0.01 *$ \\
\hline 132 & 0 & $0 \%$ & 13 & $86.7 \%$ & 0 & $0.0 \%$ & 15 & $100 \%$ & 15 & $100 \%$ & 0 & $0 \%$ & 2 & $13.3 \%$ & $0.01^{*}$ \\
\hline 170 & 1 & $100 \%$ & 13 & $86.7 \%$ & 13 & $86.7 \%$ & 13 & $86.7 \%$ & 13 & $86.7 \%$ & 0 & $0 \%$ & 12 & $80 \%$ & $0.01 *$ \\
\hline
\end{tabular}

* Significant at $P \leq 0.05$ 
TABLE (4): Number and percentage of detected kDa proteins of Strep. mutans isolated from caries free and caries active groups.

\begin{tabular}{|c|c|c|c|c|c|}
\hline \multirow[t]{2}{*}{ kDa } & \multicolumn{2}{|c|}{$\begin{array}{c}\text { Caries free groups } \\
\text { (AF, BF and CF) }\end{array}$} & \multicolumn{2}{|c|}{$\begin{array}{c}\text { Caries active group } \\
\text { (AA, BA and CA) }\end{array}$} & \multirow[t]{2}{*}{$P$ value } \\
\hline & $N=45$ & $\%$ & $N=45$ & $\%$ & \\
\hline 27 & 38 & $84.4 \%$ & 39 & $86.7 \%$ & 1.000 \\
\hline 31 & 41 & $91.1 \%$ & 39 & $86.7 \%$ & 0.74 \\
\hline 36 & 43 & $95.6 \%$ & 44 & $97.8 \%$ & 1.000 \\
\hline 40 & 41 & $91.1 \%$ & 38 & $84.4 \%$ & 0.52 \\
\hline 43 & 29 & $49.2 \%$ & 30 & $50.8 \%$ & 1.000 \\
\hline 47 & 42 & $93.3 \%$ & 45 & $100 \%$ & 0.24 \\
\hline 51 & 28 & $62.2 \%$ & 28 & $62.2 \%$ & 1.000 \\
\hline 57 & 4 & $8.9 \%$ & 7 & $15.6 \%$ & 0.52 \\
\hline 65 & 30 & $66.7 \%$ & 20 & $44.4 \%$ & 0.056 \\
\hline 68 & 40 & $88.9 \%$ & 42 & $93.3 \%$ & 0.71 \\
\hline 74 & 28 & $62.2 \%$ & 30 & $66.7 \%$ & 0.83 \\
\hline 79 & 44 & $97.8 \%$ & 42 & $93.3 \%$ & 0.62 \\
\hline 87 & 29 & $64.4 \%$ & 29 & $64.4 \%$ & 1.000 \\
\hline 92 & 39 & $86.7 \%$ & 39 & $86.7 \%$ & 1.000 \\
\hline 99 & 40 & $88.9 \%$ & 41 & $91.1 \%$ & 1.000 \\
\hline 105 & 45 & $100 \%$ & 43 & $95.6 \%$ & 0.49 \\
\hline 116 & 20 & $44.4 \%$ & 16 & $35.6 \%$ & 0.52 \\
\hline 122 & 5 & $11.1 \%$ & 16 & $35.6 \%$ & $0.01 *$ \\
\hline 132 & 17 & $37.8 \%$ & 17 & $37.8 \%$ & 1.000 \\
\hline 170 & 26 & $57.8 \%$ & 38 & $84.4 \%$ & $0.01 *$ \\
\hline
\end{tabular}

* Significant at $P \leq 0.05$

\section{DISCUSSION}

The null hypothesis of this study was partially rejected. There was a difference between tested culture media in detection of Strep. mutans. On the other hand, there were no differences in Strep. mutans protein patterns between caries free and active groups. However, young adults did show lower protein patterns than the preschool and school children.
In this study, three types of MSM were used. The difference between them is related to the type of antibiotic. MSBK and MSBT showed similar Strep. mutans recovery followed by MST (control media). The addition of antibiotics (kanamycin and bacitracin) to MST did not inhibit the growth and detection of Strep. mutans. This was in accordance to Saito et al. ${ }^{25}$. Kanamycin was added as it increases the effect of bacitracin by restraining the growth of microorganisms other than 
Strep. mutans ${ }^{11}$. The least recovery has been observed in MST where only potassium tellurite was added. Thus, the lack of bacitracin can reduce the media selectivity to Strep. mutans. In addition, various reports have shown that MST has detected non-streptococcal species ${ }^{26}$.

Although, Trypticase and GSTB media contained peptone, GSTB showed the highest CFU of Strep. mutans. Similar findings were observed by Wade et al. ${ }^{27}$. this was contrary to Singh et al. ${ }^{28}$, as Catalase and various fermentation methods were used to classify Strep. mutans instead of PCR.

The presence of glucose in addition adequate amount of sucrose in GSTB may have enriched the media for Strep. mutans growth as Strep. mutans tends to utilize monosaccharaides with subsequent disaccharides consumption ${ }^{29}$. Additionally, the presence of glucose was compensating sucrose to equalize the total amount of carbon source ${ }^{30}$. Moreover, $5 \%$ concentration of sucrose may have allowed the highest Strep. mutans count in GSTB media, as Cai et al. ${ }^{31}$ revealed that Strep. mutans growth decreased as the concentration of sucrose increased.

Although the number of Strep. mutans CFU may play a role in determining dental caries, its use as a caries risk predictor is doubtful. Therefore, it is more important to determine the virulence potential of these microorganisms ${ }^{32}$.

To exemplify the virulence identity of the isolated Strep. mutans from various age groups and caries activity patterns, the protein nature of major bands was assessed by their colorations with Coomassie blue. SDS-extracted protein patterns were explicit for Strep. mutans strains isolated from patients and were compared to the standard Strep. mutans. The molecular sizes of the discrete protein bands produced by all isolates ranged from 27 to $170 \mathrm{kDa}$.

Regarding the participant's age, $116 \mathrm{kDa}$ protein of unknown function was highly detected in preschool children. Whereas young adults showed low detection for $(43,51,65,74$ and 87$)$ cariogenic proteins. In the Kriswandini et al. study, the $45 \mathrm{kDa}$ protein ( $43 \mathrm{kDa}$ in the present study) is responsible for the aggregation of intracellular polysaccharides causing dental caries ${ }^{33}$. Whereas, the $74 \mathrm{kDa}$ protein, known as GbpA protein, has two hypercariogenic effects; it induces changes in the plaque structure resulting in stronger hindrances between tooth surface and the protective function of saliva, furthermore, it strengthens bacterial adherence to tooth surface ${ }^{34}$. The $87 \mathrm{kDa}$ protein known as protein antigen $\mathrm{C}$ is involved in bacterial attachment to the tooth surface through interaction with salivary pellicle ${ }^{35,36}$. This result was consistent with a cohort study conducted by Mejare et al. ${ }^{37}$ who revealed that dental caries progression decreased in young adults, reached a peak during the first posteruptive period and decreased by time. These findings support the fact that dental caries is accumulative by nature. This accumulation presented as DMFT cannot be considered a reliable tool for caries risk assessment unless other predisposing factors are involved. In addition, it has been reported that antibodies, especially salivary $\operatorname{IgA}$, increase over time which influence Strep. mutans pathogenic activity ${ }^{38,39}$. In the present study, young adults aged 18 to 25 were selected because caries activity in adolescents may be influenced by hormonal change during puberty, improper oral hygiene, social and psychological factors ${ }^{40,41}$.

Concerning caries behavior, no significant differences in the detected proteins were found between caries free and active in each group. It was consistent with Aldilavita et al. ${ }^{42}$ and in opposition to Tahmourespour et al. ${ }^{43}$ According to Tahmourespour et al., caries free patients had less protein bands than caries active. The conceivable clarification is that their results were based on the comparison of bands number in each group.

Several factors may contribute to this insignificant difference. The etiology of dental caries, for 
instance, involves a complex interaction between ecological and genetic factors. This includes dietary patterns in which the up-regulation of $g t f$ genes was found to be correlated with cariogenic diet ${ }^{29,36}$. The $135 \mathrm{kDa}$ protein which is presented as $132 \mathrm{kDa}$ in this study expresses the glucosyltransferase-I ( $g t f-I)$ gene present in $g t f C$. According to Kriswandini et al., this gene presumably facilitates Strep. mutans binding to tooth surface through insoluble glucans synthesis ${ }^{33,36}$. Given the role of Strep. mutans proteins in the production of caries, other $g t f$ proteins responsible for Strep. mutans virulence were not identified in this study ${ }^{29,36}$. Even later, with regard to modification of the environmental factors, persons with similar behavioral risks (i.e. tooth brushing frequency or dietary habits, quantity and quality of saliva) have different caries risk and/or activity. This reveals the hereditary contribution to caries risk ${ }^{38,44}$. In addition, the oral flora includes other species that significantly contribute to caries. Streptococcus sobrinus plays a role in the prevalence of caries when colonized with Strep. mutans ${ }^{1,45,46}$. A study by Gross et al. ${ }^{45}$ found out that some bacteria other than Strep. mutans may be the causative agents for dental caries and this might explain the caries activity in preschool children despite the absence of 132 $\mathrm{kDa}$ protein. This could be one of the limitations in this study, as it was important to study other causative bacteria for dental caries.

The caries active participants included in this study showed high detection of 122 and $170 \mathrm{kDa}$ proteins. The $122 \mathrm{kDa}$ presents CRISPR-associated protein csn $1{ }^{35}$. It helps Strep. mutans to cope with various environmental pressures contributing to its virulence potential and enhances the biofilm formation ${ }^{47}$. However, the function of $170 \mathrm{kDa}$ was not identified. Therefore, it is recommended that the identified proteins of unknown function are to be investigated using amino acids sequencing.

\section{CONCLUSIONS}

The media composition may play an important role in the recovery of Strep. mutans. Protein bands have been found more frequently in children and adolescent groups followed by young adults. More surprisingly, most of these protein bands were insignificant between caries free and caries active patients, except in two protein bands.

\section{REFERENCES}

1. Colombo NH, Kreling PF, Ribas LFF, Pereira JA, Kressirer CA, Klein MI, Tanner ACR, Duque C. Quantitative assessment of salivary oral bacteria according to the severity of dental caries in childhood. Arch Oral Biol. 2017;83:282-8.

2. Giacaman RA, Torres S, Gomez Y, Munoz-Sandoval C, Kreth J. Correlation of Streptococcus mutans and Streptococcus sanguinis colonization and ex vivo hydrogen peroxide production in carious lesion-free and high caries adults. Arch Oral Biol. 2015;60:154-9.

3. Tahmourespour A, Kermanshahi RK. The effect of a probiotic strain (Lactobacillus acidophilus) on the plaque formation of oral Streptococci. Bosn J Basic Med Sci. 2011;11:37-40.

4. Pieralisi FJ, Rodrigues MR, Segura VG, Maciel SM, Ferreira FB, Garcia JE, Poli-Frederico RC. Genotypic diversity of streptococcus mutans in caries-free and caries-active preschool children. Int J Dent. 2010;2010:824976.

5. Kawada-Matsuo M, Komatsuzawa H. Role of Streptococcus mutans two-component systems in antimicrobial peptide resistance in the oral cavity. Jpn Dent Sci Rev. 2017; 53:86-94

6. Damle SG, Loomba A, Dhindsa A, Loomba A, Beniwal V. Correlation between dental caries experience and mutans streptococci counts by microbial and molecular (polymerase chain reaction) assay using saliva as microbial risk indicator. Dent Res J (Isfahan). 2016;13:552-9.

7. Aas JA, Griffen AL, Dardis SR, Lee AM, Olsen I, Dewhirst FE, Leys EJ, Paster BJ. Bacteria of dental caries in primary and permanent teeth in children and young adults. J Clin Microbiol. 2008;46:1407-17.

8. Soncini JA, Kanasi E, Lu SC, Nunn ME, Henshaw MM, Tanner AC. Oral microbiota of children in a school-based dental clinic. Anaerobe. 2010;16:278-82. 
9. Momeni SS, Patrick P, Wiener HW, Cutter GR, Ruby JD, Cheon K, Whiddon J, Moser SA, Childers NK. Mutans streptococci enumeration and genotype selection using different bacitracin-containing media. J Microbiol Methods. 2014;103:53-7.

10. Saravia ME, Nelson-Filho P, Silva RA, De Rossi A, Faria G, Silva LA, Emilson CG. Recovery of mutans streptococci on MSB, SB-20 and SB-20M agar media. Arch Oral Biol. 2013;58:311-6.

11. Kim YH, Lee SY. Identification of non-streptococcal organisms from human dental plaque grown on the Streptococcus-selective medium mitis-salivarius agar. Arch Oral Biol. 2015;60:267-71.

12. Hasan NA,Zuhair MH, Safari E, Bozorgmehr M, Moazzeni SM. Evaluation of the effect of the $47 \mathrm{kda}$ protein isolated from aged garlic extract on dendritic cell. Iran J Basic Med Sci. 2012;15:745-51

13. Arévalo-Ruano M, Canacuán Melo F, Echeverry-Chica J, Salazar C, Martínez-Delgado C, Martinez Pabon MC, Correa M. Molecular identification and genotyping of Streptococcus mutans from saliva samples of children in Medellin, Colombia. CES Odontol. 2014;27:47-60.

14. American Academy of Pediatric Dentistry. Policy on Early Childhood Caries (ECC): Classifications, Consequences, and Preventive Strategies. Pediatr Dent. 2016;38:52-4.

15. Pitts NB, Ekstrand KR. International Caries Detection and Assessment System (ICDAS) and its International Caries Classification and Management System (ICCMS) - methods for staging of the caries process and enabling dentists to manage caries. Community Dent Oral Epidemiol. 2013;41:e41-52.

16. Mortazavi S, Akhlaghi N. Salivary Streptococcus mutans and Lactobacilli levels following probiotic cheese consumption in adults: A double blind randomized clinical trial(*). J Res Med Sci. 2012;17:57-66.

17. Kimmel L, Tinanoff N. A modified mitis salivarius medium for a caries diagnostic test. Oral Microbiol Immunol. 1991;6:275-9.

18. Gold OG, Jordan HV, Van Houte J. A selective medium for Streptococcus mutans. Arch Oral Biol. 1973;18:1357-64.

19. Linke HA. New method for the isolation of Streptococcus mutans and its differentiation from other oral streptococci. J Clin Microbiol. 1977;5:604-9.
20. Tanzer JM, Borjesson AC, Laskowski L, Kurasz AB, Testa M. Glucose-sucrose-potassium tellurite-bacitracin agar, an alternative to mitis salivarius-bacitracin agar for enumeration of Streptococcus mutans. J Clin Microbiol. 1984;20:653-9.

21. Watanabe K, Frommel TO. Detection of Porphyromonas gingivalis in oral plaque samples by use of the polymerase chain reaction. J Dent Res. 1993;72:1040-4.

22. Villhauer AL, Lynch DJ, Drake DR. Improved method for rapid and accurate isolation and identification of Streptococcus mutans and Streptococcus sobrinus from human plaque samples. J Microbiol Methods. 2017;139:205-9.

23. Oho T, Yamashita Y, Shimazaki Y, Kushiyama M, Koga T. Simple and rapid detection of Streptococcus mutans and Streptococcus sobrinus in human saliva by polymerase chain reaction. Oral Microbiol Immunol. 2000;15:258-62.

24. Laemmli UK. Cleavage of structural proteins during the assembly of the head of bacteriophage T4. Nature. 1970;227:680-5.

25. Saito $\mathrm{T}$, Ueda $\mathrm{O}$, Teramoto $\mathrm{S}$, Oguchi $\mathrm{H}$, Yanagisawa S, Miyazawa H. Bacteriological evaluation of mutans streptococci using modified mitis-salivarius-bacitracin (MSB) agar medium in primary dentition period. Pediatr Dent J. 2007;17:53-7.

26. Takada K, Hayashi K, Sasaki K, Sato T, Hirasawa M. Selectivity of Mitis Salivarius agar and a new selective medium for oral streptococci in dogs. J Microbiol Methods. 2006;66:460-5.

27. Wade WG, Aldred MJ, Walker DM. An improved medium for isolation of Streptococcus mutans. J Med Microbiol. 1986;22:319-23.

28. Singh, N. Vishnoi, Dwivedi D, Khare K, Singh V. Modified tsbb culture media enhance faster growth of streptococci mutans as compared to existing culture media. Int J Pharm Sci Res. 2016;15:3689-94.

29. Decker EM, Klein C, Schwindt D, von Ohle C. Metabolic activity of Streptococcus mutans biofilms and gene expression during exposure to xylitol and sucrose. Int $\mathbf{J}$ Oral Sci. 2014;6:195-204.

30. Kreth J, Zhu L, Merritt J, Shi W, Qi F. Role of sucrose in the fitness of Streptococcus mutans. Oral Microbiol Immunol. 2008;23:213-9.

31. Cai J-N, Jung J-E, Dang M-H, Kim M-A, Yi H-K, Jeon J-G. Functional Relationship between Sucrose and a Cariogenic Biofilm Formation. PLoS One. 2016;11:e0157184-e. 
32. Toi C, Mogodiri R. Cleaton-Jones P. Mutans streptococci and lactobacilli on healthy and carious teeth in the same mouth of children with and without dental caries. Microb Ecol Health Dis. 2000;12:35-41.

33. Kriswandini IL, Rahardjo MB, Budi HS, Amalia R. The difference in biofilm molecular weight in Streptococcus mutans and Aggregatibacter actinomycetemcomitans induced by sucrose and soy protein (glycine soja). Indian J Dent Res. 2019;30:273-6.

34. Shah DS, Russell RR. A novel glucan-binding protein with lipase activity from the oral pathogen Streptococcus mutans. Microbiology. 2004; 150:1947-56.

35. Song L, Wang W, Conrads G, Rheinberg A, Sztajer H, Reck M, Wagner-Dobler I, Zeng AP. Genetic variability of mutans streptococci revealed by wide whole-genome sequencing. BMC genomics. 2013;14:430.

36. Matsumoto-Nakano M. Role of Streptococcus mutans surface proteins for biofilm formation. Jpn Dent Sci Rev. 2018;54:22-9.

37. Mejare I, Stenlund H, Zelezny-Holmlund C. Caries incidence and lesion progression from adolescence to young adulthood: a prospective 15-year cohort study in Sweden. Caries Res. 2004;38:130-41.

38. Law V, Seow WK, Townsend G. Factors influencing oral colonization of mutans streptococci in young children. Aust Dent J. 2007;52:93-100.

39. Jafarzadeh A, Sadeghi M, Karam GA, Vazirinejad R. Salivary IgA and IgE levels in healthy subjects: relation to age and gender. Braz Oral Res. 2010;24:21-7.
40. American Academy of Pediatric Dentistry. Guideline on Adolescent Oral Health Care. Pediatr Dent. 2015; 37:49-56

41. Lukacs JR, Largaespada LL. Explaining sex differences in dental caries prevalence: saliva, hormones, and "lifehistory” etiologies. Am J Hum Biol. 2006;18:540-55.

42. Aldilavita H, P Gultom F, W Bachtiar E. Protein profiling of Streptococcus mutans isolated from the surface of the tongue in children with early childhood caries. J Phys. 2018;1073:032032.

43. Tahmourespour A, Nabinejad A, Shirian H, Ghasemipero $\mathrm{N}$. The comparison of proteins elaborated by streptococcus mutans strains isolated from caries free and susceptible subjects. Iran J Basic Med Sci. 2013;16:656-60.

44. Vieira AR, Modesto A, Marazita ML. Caries: review of human genetics research. Caries Res. 2014;48:491-506.

45. Gross EL, Beall CJ, Kutsch SR, Firestone ND, Leys EJ, Griffen AL. Beyond Streptococcus mutans: dental caries onset linked to multiple species by $16 \mathrm{~S}$ rRNA community analysis. PLoS One. 2012;7:e47722.

46. Saravia ME, Nelson-Filho P, Ito IY, da Silva LA, da Silva RA, Emilson CG. Morphological differentiation between S. mutans and S. sobrinus on modified SB-20 culture medium. Microbiol Res. 2011;166:63-7.

47. Tang B, Gong T, Zhou X, Lu M, Zeng J, Peng X, Wang $\mathrm{S}, \mathrm{Li}$ Y. Deletion of cas3 gene in Streptococcus mutans affects biofilm formation and increases fluoride sensitivity. Arch Oral Biol. 2019;99:190-7. 